\title{
Construction technology and quality control of expansion joints with rubber compensators
}

\author{
Rustem Mukhametrakhimov ${ }^{*}[0000-0003-2062-5289]$, and Indira Aliullova ${ }^{1}$ \\ Kazan State University of Architecture and Engineering, Kazan, Russia
}

\begin{abstract}
Expansion joints play an important role in the operation of bridge construction. The reliability and durability of most of the other structural elements of the bridge depend on its quality and have a significant impact on road safety. One of the most effective types of expansion joints is rubber compensators, the service life of which directly depends on the quality of its installation. In this work, the types and classifications of expansion joints of bridge construction are studied, their defects and causes of their appearance are analyzed, a visual inspection of the state of expansion joints of the bridge is performed. The technology and quality control system of technological processes for constructing $\mathrm{s}$ single-profile expansion joints with rubber compensators during the repair of bridge construction is proposed.
\end{abstract}

\section{Introduction}

Bridges belong to artificial structures, are objects of increased danger; unlike others, they are subjected to high loads from vehicles, pedestrians, natural and man-made factors, and have a long service life.

In Russia today, there are about 42 thousand bridges and overpass. Their total length is about 2.1 million running meters. Many of them have defects; some are in disrepair. The operation of damaged bridge constructions sometimes leads to emergencies. The number of accidents in bridge constructions is increasing every year; in 2018 alone, more than 100 of them occurred in Russia.

The implementation of the national project "Safe and high-quality highways" for 20172024, subprograms "Construction, reconstruction of roads and bridges", "Repair of highways and artificial structures", the state program "Development of the transport system of the Republic of Tatarstan for 2014-2024 "etc. allows to improve the problem situation in this area.

Simultaneously, a significant share of bridge constructions continues to operate with existing defects, damage and inconsistencies, which leads to a significant reduction in the overhaul life interval and their service life. One of the most common defects in bridges is a violation of the tightness of expansion joints, which entails damage to other underlying constructions.

Expansion joints (EJ) is an important element of the bridge deck. They provide a smooth and safe passage of vehicles on the road and bridge with the span of one to another,

\footnotetext{
*Corresponding author: muhametrahimov@mail.ru
} 
eliminate the noise of the wheels, the appearance of vibrations etc. [1]. The reliability and durability of other structural elements of the bridge structure depend on expansion joints. Thus, if the expansion joint is damaged in the zone of influence of aggressive waters flowing from the carriageway, through it, the structures of the span structure, supporting parts, cabinet walls, abutment stones, etc. [2]. Expansion joints also have a significant impact on road safety.

In this regard, relevant questions are aimed at the timely repair of expansion joints. Joints with rubber compensators are widely used in repairs to which the following requirements are imposed: tightness, long service life, compliance with safety conditions during operation, the possibility of technical inspection, ease of installation, minimum operating costs [3-4]. At the same time, it should be noted that the required durability of the repaired expansion joints is often not ensured, which is associated with a violation of the production technology and quality control.

Because of the foregoing, work aimed at solving the issues of improving the quality control system for the device of expansion joints during the repair of bridge constructions is acquiring special relevance.

Analysis of the literature data made it possible to single out several works that deal with the quality of design, construction, repair and operation of bridge constructions. In a series of works [5-8], the authors provide examples of numerous accidents and destruction of bridge constructions with an analysis of the causes of their occurrence. The paper [9] gives an example of non-compliance with quality control during the production of welding works of the span structure and failure to perform anti-corrosion treatment of bolted joints. This led to the collapse of the bridge over the Mianus River in 1983. Another emergency case is given in the article [10], a bridge over the Vorona River near Borisoglebsk collapsed due to non-compliance with the production technology of repair work. In many works, the authors pay attention to important issues of the quality of materials [11-15], quality control requirements [16-20], modern production technologies [21-23] during repair work on the supports of bridges, bridge deck, etc. Without diminishing the significance of the works discussed above, it should be noted that the features of the technology of the device and quality control of joints with rubber compensators are not adequately considered.

The purpose of this work is to improve the quality control system of technological processes for the device of expansion joints with rubber compensators during the repair of bridge constructions.

\section{Methods}

At the first stage of the research, the analysis and classification of the types of expansion joints of bridge structures were provided. Research methods such as classification, analysis and generalization were applied.

At the second stage, a visual inspection of the technical condition of the expansion joints of bridge constructions in Kazan was carried out, their main defects and damages were systematized. The inspection was carried out by visual, measuring and observational methods. During the inspection, defects and damage to the expansion joints were identified, they were fixed, and the damage was described.

At the third stage, the requirements for quality control of the device of expansion joints with a rubber compensator are systematized. Methods of systematization, generalization, description and analysis were used.

To determine the geometric deviations, a set of visual measuring control (VIC) was used, including a steel ruler, a caliper with a depth gauge, a reference square, a magnifying glass, a $5 \mathrm{~m}$ tape measure, a pocket flashlight, etc. A Canon EOS 1100D Kit was used to photograph defects. 


\section{Results and Discussion}

\subsection{Analysis and classification of types of expansion joints of bridge constructions}

According to [24], expansion joints can be classified by the appearance of the structure itself into an open type - the structure is an unfilled gap; closed type - the construction of the expansion joint is closed from above by the covering of the roadway; filled type - the joint structure is filled with material, but the coating roadway formed with a gap; covered type - the structure is covered at the level of the carriageway.

There is a classification by filling material for filled type joints - with and without mastic filling and steel edging, with and without rubber filling and steel edging.

For covered type joints - classification by the type of overlapping element: overlapping reinforced concrete slab, sliding sheet, etc. [25]. For open type joints, there is a classification according to the presence or absence of steel edging, which affects the width of the visible gap. Closed joints are classified as: having a reinforced coating and not having [25].

\subsection{Major defects and damage to expansion joints of bridge construction}

Damage to expansion joints and disruption of their operation is noticeable during visual inspection not only of the joints themselves but also of structures located below them, for example, supports, supporting parts, etc. [26]. Defects of expansion joints can be conditionally divided into two main groups [27]: violation of tightness and violation of smoothness of passage that is damage to the pavement.

Leaks of various kinds, destruction of drainage trays are related to leakage damage. Damage to the pavement consists of cracks at the joint or above it, destruction of the pavement itself in its zone, destruction of filling layers of pavement [27].

The main causes of defects are low deformability of asphalt concrete, violation of technology during work, incorrect or untimely repairs, erroneous design decisions, low durability of materials.

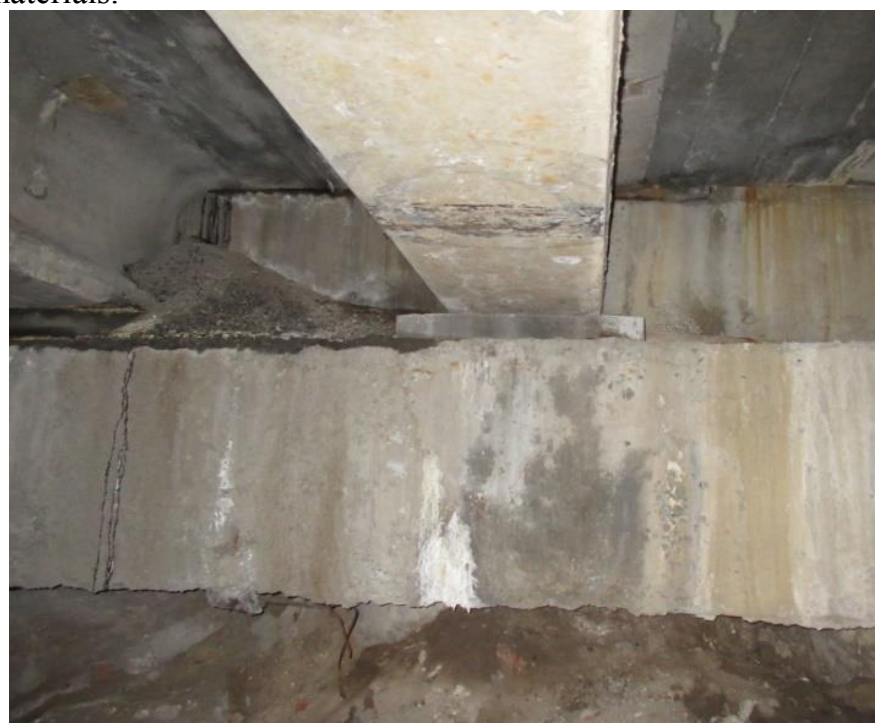

Fig. 1. Water ingress on the supporting parts of the bridge structure 


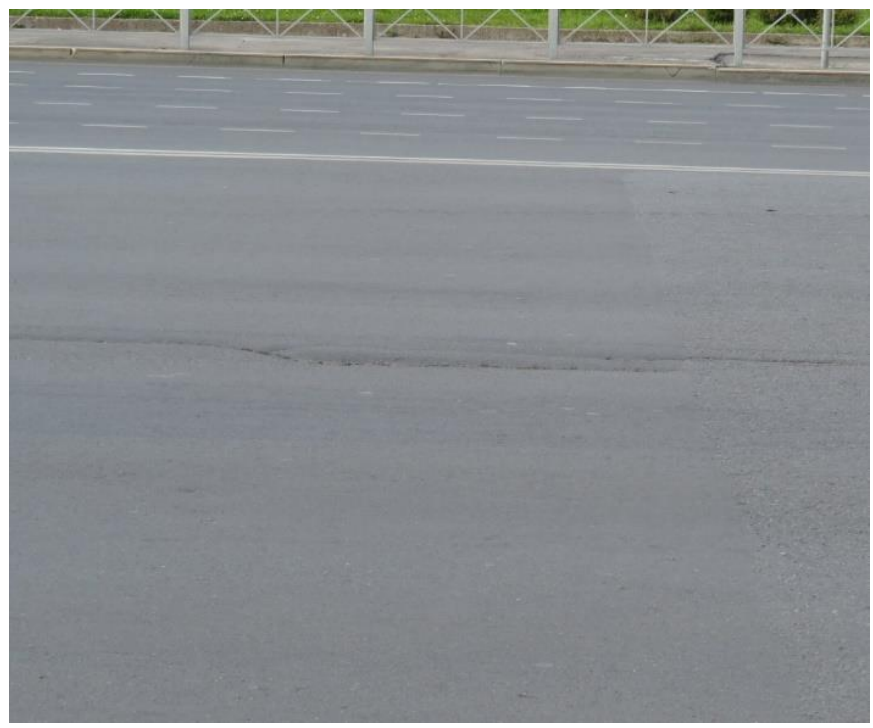

Fig. 2. Destruction of the roadway surface in the area of the EJ

So, on Bulachny bridge in Kazan, the tightness of the expansion joint structure was broken, as a result of which, during the passage of atmospheric precipitation, surface water ingress and the underlying structure is contaminated (Fig. 1). The wear of the expansion joint does not ensure smooth mating with the roadway surface and leads to an increase in the dynamic effect of temporary load on the supporting structures (Fig. 2).

\subsection{Single-profile technology of the expansion joint with rubber compensator}

For repairing EJ bridges, a single-profile expansion joint with a rubber compensator (Fig. 3 ) is effective, which ensures complete tightness, creates more reliable structures for small movements, excludes the construction of complex drainage trays, the device of which is sometimes impossible.

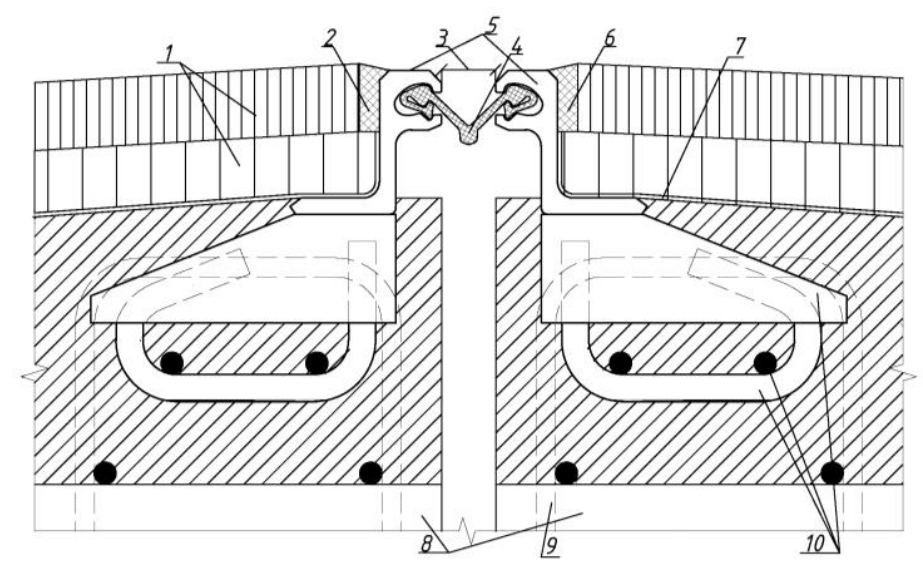

Fig. 3. The scheme of an expansion joint with a rubber compensator: 1 is pavement on the carriageway, 2 is mastic, 3 is EJ disclosure, 4 is compensator, 5 is EJ beams, 6 is mastic, 7 is waterproofing layer, 8 is reinforced concrete of the span structure, 9 is EJ anchor plate binding 10 is joint fitting. 
The design of the EJ with rubber compensators is used in reinforced concrete and steelreinforced concrete spans of bridges provides displacement up to $100 \mathrm{~mm}$.

The advantages of this type of expansion joints are [28]: ease of installation, smooth passage, noise reduction, reduced labor intensity, relatively low cost. As for disadvantages, one can single out the relatively little possibility of movement $\leq 100 \mathrm{~mm}$; the EJ is not provided for the device in seismically active construction areas; precise quality control is required at the entire installation stage [28].

The production technology of work is relatively small in terms of labor intensity compared to others. According to STO NOSTROY 2.29.104-2013, one of the main requirements for the quality of preparatory work is the correct assembling, i.e. unification of completely transported sections. It is important that the rubber for the expansion joint is supplied separately from the sections and is solid, with the exception of the cases provided for by the project, which take into account the presence of a vulcanizer at the construction site to connect rubber expansion joints [29].

Basic operation begins with forming a niche in the span structure and the closet wall (Fig. 4). Then the design of the EJ construction itself is installed in the design position so that the pavement is $10-15 \mathrm{~mm}$ higher than the top of the EJ. To close the vertical plates of the edges of the bordering with concrete, the EJ should be installed so that the vertical plates of the ribs of the bearing beams are at a distance of at least $30 \mathrm{~mm}$ from the vertical plane of the cabinet wall.

Further, the joint itself is extended by the amount specified in the design documentation, the outlets of the reinforcement slabs of the roadway are welded with border anchors, and the mounting frame is removed. To avoid the formation of a fracture during waterproofing, the top of the concrete for grouting the niche must coincide with the upper surface of the legs of the supporting EJ beams.

Further, the anchoring nodes of the border are concreting, waterproofing is arranged with an institution for the border leg.

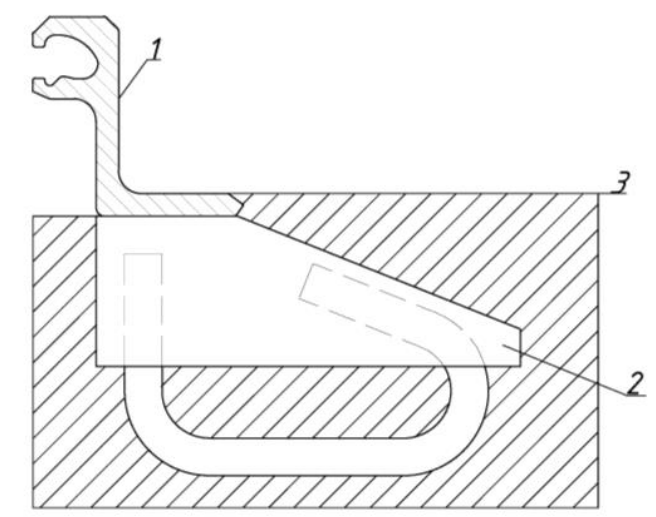

Fig. 4. The scheme of the device of a niche in the stove (illustration by the authors): 1 is EJ beam, 2 is anchor plate, 3 is concrete level.

Quality control of the device of a single-profile expansion joint with a rubber compensator.

The authors have systematized the requirements for quality control of the device of expansion joints with a rubber compensator. The list of controlled operations, means of control and the necessary documentation for constructing a single-profile expansion joint with a rubber compensator are shown in the table. 
Table 1. The composition of operations and means control

\begin{tabular}{|c|c|c|c|}
\hline Phase of work & Controlled operations & Control & Documentation \\
\hline $\begin{array}{c}\text { Preparatory } \\
\text { work }\end{array}$ & $\begin{array}{l}\text { Verify: } \\
\text { - availability of a document } \\
\text { on the quality of the EJ; } \\
\text { - the quality of the end } \\
\text { surfaces of the gusset plates, } \\
\text { the width of the rubber } \\
\text { expansion joints; } \\
\text { - the presence of an inspection } \\
\text { certificate for previously } \\
\text { performed work; } \\
\text { - the presence of approximate } \\
\text { marks that determine the } \\
\text { design position. }\end{array}$ & $\begin{array}{c}\text { Visual } \\
\begin{array}{c}\text { Measuring, each } \\
\text { element }\end{array} \\
\text { Visual } \\
\text { Visual }\end{array}$ & $\begin{array}{l}\text { Passports (quality } \\
\text { certificates), general } \\
\text { work log, certificate } \\
\text { of examination } \\
\text { (acceptance) of } \\
\text { previously performed } \\
\text { work. }\end{array}$ \\
\hline $\begin{array}{c}\text { Expansion joint } \\
\text { device }\end{array}$ & $\begin{array}{c}\text { Control: } \\
\text { - installation of the expansion } \\
\text { joint in the design position; } \\
\text { - parallelism of axes, edging, } \\
\text { absence of relative } \\
\text { displacements of elements } \\
\text { connected by welding; } \\
\text { - the width of the gap between } \\
\text { the edging; } \\
\text { - presence of rust and places } \\
\text { untreated with mastic; } \\
\text { - the presence of cracks and } \\
\text { leaks at the point where the } \\
\text { expansion joints are attached } \\
\text { to the edging; } \\
\text { - welding works }\end{array}$ & $\begin{array}{c}\text { Measuring } \\
\text { Visual } \\
\text { Visual }\end{array}$ & General work log \\
\hline $\begin{array}{l}\text { Acceptance of } \\
\text { completed } \\
\text { works }\end{array}$ & $\begin{array}{l}\text { Verify: } \\
\text { - the actual position of the EJ; } \\
\text { - waterproofing, tightness. }\end{array}$ & $\begin{array}{l}\text { Measuring, visual } \\
\text { Visual }\end{array}$ & $\begin{array}{l}\text { Certificate of } \\
\text { survey (acceptance) } \\
\text { of work performed, } \\
\text { executive geodetic } \\
\text { scheme }\end{array}$ \\
\hline \multicolumn{4}{|c|}{$\begin{array}{l}\text { Control and measuring tool: plumb rail, building level, metal ruler, level, theodolite, caliper. } \\
\text { Operational control is implemented by: master or foreman, surveyor - in the process. } \\
\text { Acceptance control is implemented by: quality service workers, master or foreman, } \\
\text { representatives of the customer's technical supervision. }\end{array}$} \\
\hline
\end{tabular}

\section{Conclusions}

1. The analysis is provided, and the classification of the types of expansion joints of bridge structures is given. The dependence of the reliability and durability of structural elements of bridges on the quality of expansion joints is shown.

2. Based on the performed visual inspection of the technical condition of the expansion joints of bridge constructions and the analysis of literature data, the main defects and damages are systematized. It was found that the main defect is leakage, which leads to a decrease in durability and disruption of the rest of the bridge structures.

3. It has been determined that one of the effective types of expansion joints for the repair of bridge constructions is a single-profile joint with a rubber compensator. However, the quality of the construction of such joints often does not meet regulatory requirements. 
4. The technology is presented, and the system of quality control of technological processes of the device of single-profile expansion joints with rubber compensators during the repair of bridge constructions is proposed.

\section{References}

1. Kozlachkov, S. V., Ovchinnikov, I. I., Ovchinnikov, I. G.: Requirements to expansion joints of the bridge constructions. New Ideas of New Century: materials of the international scientific conference FAD PSU. 2, 340-345 (2013).

2. Efanov A.V., Ovchinnikov I. G.: Static and dynamic analysis of expansion joints of motorway bridges. Vestnik of the Volgograd State University of Architecture and Civil Engineering. Series: Construction and architecture. 6, 102-106 (2006).

3. Alekseev S. V., Trepalin V. A., Shevchenko S. M., Trifonova A. A.: Modern methods of improving the construction of expansion joints of motorway bridges. Putevoy navigator. 43 (69), 3 (2020). DOI: 10.15862/20SATS220.

4. Kozlachkov S. V., Ovchinnikov I. I., Ovchinnikov I. G.: Domestic expansion joints of the bridge buildings. New Ideas of New Century: materials of the international scientific conference FAD PSU. 328-333 (2013).

5. Maystrenko, I., Ovchinnikov, I., Ovchinnikov, I., Kokodeev, A.: Failures and collapses of bridge constructions, analysis of their causes. Part 1. Russ. J. Transp. Eng. (2017). DOI: 10.15862/13ts417.

6. 5. Maystrenko, I., Ovchinnikov, I., Ovchinnikov, I., Kokodeev, A.: Failures and collapses of bridge constructions, analysis of their causes. Part 2. Russ. J. Transp. Eng. (2017). DOI: $10.15862 / 14$ ts417.

7. 6. Maystrenko, I., Ovchinnikov, I., Ovchinnikov, I., Uspanov, A.: Failures and collapses of bridge constructions, analysis of their causes. Part 3. Russ. J. Transp. Eng. (2018). DOI: $10.15862 / 08$ sats 118 .

8. 7. Ovchinnikov, I., Maystrenko, I., Ovchinnikov, I., Uspanov, A.: Failures and collapses of bridge constructions, analysis of their causes. Part 4. Russ. J. Transp. Eng. (2018). DOI: 10.15862/05sats118.

9. Karamysheva, A. A., Stroyev, D. A., Kolotienko M. A., Konik A. I.: Analysis and systematization of the causes of bridge structures destruction. Inzhenernyy vestnik Dona. 3 (54), 34 (2019).

10. Kozyreva, L.V., Kitar, Ye.V.: Accidents on the bridge construction. Tekhnicheskoye regulirovaniye v transportnom stroitel'stve. 1 (9), 37-42 (2015).

11. Pipinato, A.: Innovative bridge design handbook: Construction, rehabilitation and maintenance. (2015).

12. Chen, W. F., Duan, L. (Eds.): Bridge Engineering Handbook: Superstructure Design. Second Edition. Boca Raton, FL : CRC Press. (2014).

13. Vdovin, E., Mavliev, L., Stroganov, V.: Interaction of clay soil components with portland cement and complex additive based on octyltriethoxysilane and sodium hydroxide. In: IOP Conference Series: Materials Science and Engineering (2020). DOI: 10.1088/1757-899X/890/1/012031.

14. Khuzin, A., Sharavina, A.: Ways to improve the quality of monolithic reinforced concrete structures. In: IOP Conference Series: Materials Science and Engineering (2020). DOI: 10.1088/1757-899X/890/1/012127.

15. Pimenov, S.I.: Features of the structure formation of a cement stone after hydromechanochemical activation of cement. Russ. J. Build. Constr. Archit. 49, 46-58 (2019).

16. Mukhametrakhimov, R.K., Lukmanova, L.V., Kamaliev, M.I.: Features of the quality control system of the installation of hinged ventilated facade systems. Izv. KGASU. 
43, 234-240 (2018).

17. Mukhametrakhimov, R.K., Aliullova I.R..: Improvement of the quality control system for expansion joints with rubber compensators during the repair of bridge constructions. Izv. KGASU. 3, 47-55 (2020).

18. Mukhametrakhimov, R.K., Panchenko, A.A.: Features of the quality control system for the construction of outdoor water supply and sewerage networks. Izv. KGASU. 4, 360-367 (2017).

19. Mukhametrakhimov, R.K., Panchenko, A.A.: Features of technology of installation and quality control of pipelines with polyfoam polyethylene insulation. Izv. KGASU. 44, 246-254 (2018).

20. Panchenko, A.A., Mukhametrakhimov, R.K., Galautdinov, A.R.: Control system for the construction of outdoor water supply and sewerage network. Resource-and energy-efficient technologies in the construction complex of the region. 10, 43-46 (2018).

21. Pimenov, S.: Heavyweight Concrete Based on Hydromechanochemically Activated Binder. In: IOP Conference Series: Materials Science and Engineering (2020). DOI: 10.1088/1757-899X/890/1/012098.

22. Mukhametrakhimov, R., Lukmanova, L.: Influence of the technological properties of cement-sand mortar on the quality of 3D printed products. In: IOP Conference Series: Materials Science and Engineering (2020). https://doi.org/10.1088/1757899X/890/1/012082.

23. Mukhametrakhimov, R.K., Vakhitov, I.M.: Additivnaya tekhnologiya vozvedeniya zdaniy i sooruzheniy s primeneniyem stroitelnogo 3D-printera. Izvestiya KGASU. 4, 350-359 (2017).

24. Berlov, S. A., Ovchinnikov, I. I.: Comparative analysis of ways to protect bridge structures from external influences. Transportnyye sooruzheniya. 7 2, 1 (2020). DOI: 10.15862/20SATS220.

25. Kozlachkov, S. V., Ovchinnikov, I. I., Valiev, Sh. N., Ovchinnikov, I. G.: Requirements to expansion joints of the bridge buildings. Online Journal Naukovedeniye. 3 (12), 34 (2012).

26. Ovchinnikov, I. G., Rasporov, O. N., Ovchinnikov, I. I.: The main problems of the national bridge building. Modernizatsiya i nauchnyye issledovaniya $\mathrm{v}$ transportnom komplekse. 437-442 (2015).

27. Ovcearenco, E.: Construction and arrangement of bridge deformation joints with elastic compensator: dig. of art. VII International Scientific and Practical Conference Additional Science / Penza. 46 (2019).

28. Eremeev, V.P.: Limit and emergency conditions of bridge.: Kazan, KSAACE. (2004).

29. Hithesh, H., Naik, K., Dr. Ravindra, B., Manjunath, H.S.: Nonlinear Analysis of the Bridge Expansion Joint Sealing. International Research Journal of Engineering and Technology (IRJET). pp. 1281-1284 (2018). 